\title{
ANALISIS PENGARUH RASIO PROFITABILITAS DAN ECONOMIC VALUE ADDED (EVA) TERHADAP RETURN SAHAM \\ Studi pada Perusahaan yang Tercatat Aktif dalam LQ 45 di BEI Perioda 2008-2012
}

\author{
Triwahyuningtyas \\ Beni Suhendra Winarso
}

\begin{abstract}
This research aims to analyse the influence of the ratio of profitability and economic value added (EVA) company shares in return for the period 2008-2012 $L Q$ 45. Data obtained from icmd and stock prices publication with a period of 2008-2012.This research is a population of 45 companies and the total sample as many as 12 companies with sampling purposive past the stage. Dependent variable used in research is return stock, while the independent variable in the research is the ratio of profitability consisting of return on investment (ROI), net profit margin (NPM), gross profit margin ( gpm ), earnings per share (EPS), and economic value added (EVA). Research result indicates that in the $f$ roi, said the independent variable npm, gpm, eps, the yield on the first day, and eve three days before, and $d d-4$, influential jointly on the dependent variable (shares) and return on the first day because of return (0,032) $\mathrm{H}-3$ ( 0,008) and $\mathrm{H}-4$ ( 0,045) have a significance \& it; 0.05. While this suggests that roi thave influence on the yield on the yield $H+1$ first day, and three days before, npm have influence on $H-4$ shares in return, return gpm have influence on the yield on the stocks return $H+2$ eps has an effect on the yield on the stocks return $h$ and eva have influence on the yield on $\mathrm{H}-3$ and $\mathrm{H}-2$ of return
\end{abstract}

Keywords: ROI, NPM, GPM, EPS, EVA, returns on stocks and LQ 45

\section{PENDAHULUAN}

Pasar modal Indonesia mengalami perkembangan yang sangat pesat dari perioda ke perioda, hal tersebut terbukti dengan meningkatnya jumlah saham yang ditransaksikan dan semakin tingginya volume perdagangan saham. Sejalan dengan perkembangan yang pesat tersebut, kebutuhan akan informasi yang relevan dalam pengambilan keputusan investasi di pasar modal juga semakin meningkat (Ang, 1997).

Pasar modal adalah pertemuan antara pihak yang memiliki kelebihan dana dengan pihak yang membutuhkan dana dengan cara memperjualbelikan sekuritas. 
Sedangkan tempat terjadinya jual beli sekuritas disebut dengan bursa efek (Tandelilin, 2001). Tujuan investor dalam berinvestasi adalah memaksimalkan return, tanpa melupakan faktor risiko investasi yang harus dihadapinya.

Salah satu faktor penting yang harus diketahui oleh para calon investor, yaitu return on investment (ROI), yang menggambarkan tingkat laba yang diperoleh perusahaan dengan tingkat investasi yang ditanamkan. ROI digunakan untuk menggambarkan kemampuan aset-aset yang dimiliki perusahaan dalam menghasilkan laba (Tandelilin, 2001). Selain ROI, ada juga earning per share (EPS) merupakan perbandingan antara earning (dalam hal ini laba bersih setelah pajak) dengan jumlah lembar saham perusahaan. Bagi para investor, informasi EPS merupakan informasi yang dianggap paling mendasar dan berguna, karena bisa menggambarkan prospek earning di perusahaan masa depan (Tandelilin, 2001). Ada pula rasio net profit margin (NPM) merupakan rasio antara laba bersih setelah pajak (EAT) terhadap penjualan (sales) (Savitri, 2012).

Gross profit margin (GPM) adalah rasio untuk mengukur selisih antara penjualan dengan harga pokok penjualan/laba kotor dengan penjualan yang dilakukan (Sartono, 2000). GPM adalah kemampuan dalam memperoleh laba kotor dalam hubungannya dengan penjualan (Martono, 2008). Menurut Sjarief (2004) dalam Christanty (2009) sejak tahun 1990 dunia bisnis mengenal alat baru untuk mengukur kinerja keuangan pada suatu perusahaan, alat ini dikenal dengan nama economic value added (EVA). EVA pertama kali diperkenalkan oleh George Bennet Stewart III dan Joel M. Stern (1993), analis keuangan di dalam kantor konsultan Stern Stewart Management Service of NewYork, Amerika Serikat.

Penelitian terdahulu dilakukan oleh Mulyanti (2009) dan Hidayatulloh (2012) menunjukkan bahwa ROI berpengaruh signifikan terhadap return saham. Hasil penelitian Mayasari menunjukkan ROI tidak berpengaruh terhadap return saham. Sedangkan penelitian yang dilakukan oleh Hidayatulloh (2012) menunjukkan bahwa ROI berpengaruh terhadap return saham pada perusahaan yang terdaftar di 
LQ 45. Oleh karena itu, perlu dilakukan penelitian lebih lanjut untuk mengetahui bagaimana pengaruh ROI terhadap return saham.

Rasio pasar merupakan rasio yang menggambarkan harapan-harapan investor terhadap investasi yang ditanamkan. Rasio ini menunjukkan informasi penting perusahaan yang diungkapkan dalam basis per saham (Ang, 1997). Berdasarkan penelitian Hidayatulloh (2012) dan Christanty (2009) menunjukkan bahwa EPS berpengaruh terhadap return saham. Sedangkan penelitian yang dilakukan oleh Riyani (2011) yang meneliti return saham pada perusahaan LQ 45 BEI selama tahun 2004 sampai dengan tahun 2010, menunjukkan bahwa EPS tidak berpengaruh terhadap return saham.

Penelitian Riyani (2011) yang meneliti NPM serta pengaruhnya terhadap return saham pada perusahaan LQ 45 BEI selama tahun 2004 sampai dengan tahun 2010 menunjukkan bahwa NPM berpengaruh terhadap return saham. Begitu pula dengan Christanty (2009) yang menunjukkan bahwa NPM berpengaruh signifikan terhadap return saham.

GPM menggambarkan efisiensi pengendalian harga pokok atau biaya produksinya, mengindikasikan kemampuan perusahaan untuk berproduksi secara efisien. Hasil penelitian yang dilakukan oleh Amalia (2011) tentang pengaruh kinerja keuangan terhadap harga saham pada perusahaan property dan real estate yang terdaftar di BEI tahun 2006-2011, menunjukkan bahwa GPM berpengaruh terhadap harga saham. Begitupula penelitian Riyani (2011) yang menunjukkan bahwa GPM berpengaruh terhadap return saham.

Penilaian kinerja dengan menggunakan EVA menyebabkan perhatian manajemen sesuai dengan kepentingan pemegang saham. Hasil penelitian Mulyanti (2009) menunjukkan bahwa EVA berpengaruh signifikan terhadap return saham. Penelitian lain yaitu Christanty (2009) yang dilakukan selama tahun 2003 sampai dengan tahun 2007, menunjukkan bahwa EVA berpengaruh signifikan terhadap return saham. Hasil yang diperoleh menunjukkan bahwa dari EVA berpengaruh signifikan terhadap return saham. Berdasarkan data dan pernyataan-pernyataan 
yang telah diuraikan maka penelitian ini bermaksud menganalisis pengaruh rasio profitabilitas dan economic value added (EVA) terhadap return saham (studi pada perusahaan yang tercatat aktif dalam LQ 45 perioda 2008-2012).

\section{TINJAUAN PUSTAKA DAN PENGEMBANGAN HIPOTESIS \\ Bursa Efek}

Lembaga yang menyelenggarakan perdagangan efek adalah Bursa Efek di Indonesia. Bursa Efek harus berbentuk perseroan. Menurut Susilo (2009) dalam Hidayatulloh (2012) Bursa Efek Indonesia memperkenalkan beberapa macam indeks untuk memudahkan analisis dan pemodal mempelajari pasar modal sehingga diperoleh informasi yang paling sesuai dengan kebutuhan analisis dan pemodal. Indeks harga saham yang terdapat di Bursa Efek Indonesia yaitu Indeks Harga Saham Gabungan (IHSG), Indeks Harga Saham Individual (IHSI), Indeks BI-40, Indeks Sektoral, Indeks LQ 45, Jakarta Islamic Index (JII), Indeks JBA-25, Indeks Kompas-100, dan Indeks Bisnis-27.

\section{Pasar Modal}

Pasar modal adalah pertemuan antara pihak yang memiliki kelebihan dana dengan pihak yang membutuhkan dana dengan cara memperjualbelikan sekuritas (Tandelilin, 2007). Menurut Kusumastuti (2009) dalam Savitri (2012) pasar modal (capital market) merupakan pasar untuk berbagai instrumen keuangan jangka panjang yang bisa diperjualbelikan, baik dalam bentuk utang, ekuitas (saham), instrumen derivatif, maupun instrumen lainnya. Pasar modal merupakan sarana pendanaan bagi perusahaan maupun institusi lain (misalnya pemerintah) dan sarana bagi kegiatan berinvestasi. Dengan demikian, pasar modal memfasilitasi berbagai sarana dan prasarana kegiatan jual beli dan kegiatan terkait lainnya

\section{Saham}

Saham merupakan surat bukti bahwa kepemilikan atas aset-aset perusahaan yang menerbitkan saham. Dengan memiliki saham suatu perusahaan, maka investor 
akan mempunyai hak terhadap pendapatan dan kekayaan perusahaan, setelah dikurangi dengan pembayaran semua kewajiban perusahaan. Saham merupakan salah satu jenis sekuritas yang cukup popular diperjualbelikan di pasar modal (Tandelilin, 2007). Ada dua jenis saham, yaitu:

1. Saham preferen adalah saham yang mempunyai kombinasi karakteristik gabungan dari obligasi maupun saham biasa, karena saham preferen memberikan pendapatan yang tetap seperti halnya obligasi, dan juga mendapatkan hak kepemilikan seperti pada saham biasa.

2. Saham biasa adalah sekuritas yang menunjukkan bahwa pemegang saham biasa tersebut mempunyai hak kepemilikan atas aset-aset perusahaan.

\section{Return Saham}

Return adalah laba atas suatu investasi yang biasanya dinyatakan sebagai tarif persentase tahunan. Return saham merupakan tingkat keuntungan yang akan diperoleh oleh investor yang menanamkan dananya di pasar modal. Return saham ini dapat dijadikan sebagai indikator dari kegiatan perdagangan di pasar modal. Menurut Jogiyanto (2003), return saham dibedakan menjadi dua yaitu return realisasi (realized return) dan return ekspektasi (expected return).

\section{Indeks LQ 45}

Indeks LQ 45 adalah nilai kapitalisasi pasar dari 45 saham yang paling likuid dan memiliki nilai kapitalisasi yang besar hal itu merupakan indikator likuidasi. Indeks LQ 45, menggunakan 45 saham yang terpilih berdasarkan likuiditas perdagangan saham. Saham-saham pada indeks LQ 45 harus memenuhi kriteria dan melewati seleksi utama sebagai berikut:

1. Masuk dalam ranking 60 besar dari total transaksi saham di pasar regular (ratarata nilai transaksi selama 12 bulan terakhir).

2. Ranking berdasar kapitalisasi pasar (rata-rata kapitalisasi pasar selama 12 bulan terakhir).

3. Telah tercatat di BEI minimum tiga bulan 
4. Keadaan keuangan perusahaan dan prospek pertumbuhannya, frekuensi dan jumlah hari perdagangan transaksi pasar reguler.

\section{Rasio Profitabilitas}

Profitabilitas adalah kemampuan perusahaan memperoleh laba dalam hubungannya dengan penjualan, total aktiva, maupun modal sendiri. Dengan demikian bagi investor jangka panjang akan sangat berkepentingan dengan analisis profitabilitas ini, misalnya bagi pemegang saham akan keuntungan yang benarbenar akan diterima dalam bentuk dividen (Sartono, 1994). Rasio profitabilitas yang digunakan dalam penelitian ini adalah return on investment (ROI), earnings per share (EPS), net profit margin (NPM), dan gross profit margin (GPM).

\section{Economic Value Added (EVA)}

EVA adalah ukuran keberhasilan manajemen perusahaan dalam meningkatkan nilai tambah bagi perusahaan. EVA dihitung dengan mengurangkan keuntungan operasi perusahaan dengan biaya modal perusahaan, baik untuk biaya utang (cost of debt) maupun modal sendiri (cost of equity). Jika perbedaan tersebut positif, berarti ada nilai tambah bagi perusahaan, dan ini biasanya akan direspon oleh meningkatnya harga saham. Demikian pula sebaliknya jika EVA negatif berarti perusahaan mengalami penurunan kinerja, yang biasanya akan direspon dengan penurunan harga saham perusahaan (Tandelilin, 2007).

\section{Pengaruh Return on Investment (ROI) dengan Return Saham}

ROI merupakan rasio antara laba setelah pajak (EAT) terhadap total assets. ROI semakin meningkat menunjukkan kinerja perusahaan yang semakin baik. Pemegang saham akan memperoleh keuntungan dari dividen yang diterimanya karena dividen semakin meningkat. Dividen yang diterima semakin meningkat tersebut merupakan daya tarik bagi para investor/calon investor untuk menanamkan modalnya ke dalam perusahaan tersebut. Jika permintaan atas saham perusahaan semakin banyak maka harga saham perusahaan tersebut di pasar modal cenderung 
meningkat. Hal ini didukung oleh penelitian Mulyanti (2009), Nugraha (2009), Hidayatulloh (2012), dan Riyani (2011) yang memperoleh hasil bahwa ROI berpengaruh terhadap return saham. Dari uraian tersebut dapat dihipotesiskan sebagai berikut:

$\mathrm{H}_{1}$ : Return on investment (ROI) berpengaruh terhadap return saham perusahaan yang terdaftar di LQ 45.

\section{Pengaruh Earning per Share (EPS) dengan Return Saham}

Perusahaan yang mengalami pertumbuhan EPS diisyaratkan mempunyai kinerja yang baik oleh investor, karena pembayaran dividen oleh perusahaan sangat tergantung dengan pertumbuhan laba, sehingga perusahaan yang mengalami pertumbuhan laba akan direspon oleh investor, respon ini dapat dilihat dari perubahan harga saham perusahaan tersebut yang pada akhirnya perubahaan harga saham akan mempengaruhi return saham. Hal ini didukung oleh penelitian Christanty (2009), Hidayatulloh (2012), dan Nugraha (2009) yang memperoleh hasil bahwa EPS berpengaruh terhadap return saham. Berdasar uraian tersebut dapat dihipotesiskan sebagai berikut:

$\mathrm{H}_{2:}$ Earning per share (EPS) berpengaruh terhadap return saham perusahaan yang terdaftar di LQ 45.

\section{Pengaruh Net Profit Margin (NPM) dengan Return Saham}

NPM yang tinggi memberikan sinyal akan keberhasilan perusahaan dalam mengemban misi dari pemiliknya. Perusahaan yang mampu menghasilkan keuntungan akan mempengaruhi investor/calon investor untuk melakukan investasi. NPM perusahaan yang meningkat akan menyebabkan investor memburu suatu saham perusahaan akibatnya return saham perusahaan tersebut akan meningkat (Nathaniel, 2008). Hal ini didukung oleh penelitian Christanty (2009) dan Riyani (2011) yang memperoleh hasil bahwa NPM berpengaruh terhadap return saham. Berdasar uraian diatas dapat dihipotesiskan sebagai berikut: 
$\mathrm{H}_{3}$ : Net profit margin (NPM) berpengaruh terhadap return saham perusahaan yang terdaftar di LQ 45.

\section{Pengaruh Gross Profit Margin (GPM) dengan Return Saham}

GPM menunjukkan kemampuan manajemen untuk menghasilkan laba kotor sehubungan dengan penjualan yang dilakukan sehingga perusahaan dapat memperoleh laba, semakin tinggi GPM semakin baik pertumbuhan laba perusahaan. GPM yang tinggi mempengaruhi return saham. Hal ini didukung oleh penelitian Amalia (2011) dan Maftukhah (2011) yang memperoleh hasil bahwa GPM berpengaruh terhadap return saham. Berdasar uraian tersebut dapat dihipotesiskan sebagai berikut:

$\mathrm{H}_{4}$ : Gross profit margin (GPM) berpengaruh terhadap return saham perusahaan yang terdaftar di LQ 45.

\section{Pengaruh Economic Value Added (EVA) dengan Return Saham}

EVA adalah suatu sistem manajemen keuangan untuk mengukur ekonomi dalam suatu perusahaan yang menyatakan bahwa kesejahteraan hanya dapat diciptakan jika perusahaan mampu memenuhi semua biaya operasi/operating cost dan biaya modal/cost of capital (Mirza, 1999). EVA mencerminkan seberapa besar perusahaan mampu memberdayakan modal dengan baik. Adanya pemberdayaan modal tersebut berakibat pada keuntungan perusahaan. Dengan demikian juga akan mempengaruhi nilai return perusahaan. Hal ini didukung oleh penelitian Christanty (2009), Mayasari (2006), Mulyanti (2009) dan Nugraha (2009) yang memperoleh hasil bahwa EVA berpengaruh terhadap return saham. Berdasar uraian tersebut dapat dihipotesiskan sebagai berikut:

$\mathrm{H}_{5}$ : Economic value added (EVA) berpengaruh terhadap return saham perusahaan yang terdaftar di LQ 45. 
Model Penelitian

Variabel Independen

\begin{tabular}{|l|}
\hline Return on Investment $(\mathrm{ROI})\left(\mathrm{X}_{1}\right)$ \\
\hline Marjin Keuntungan $\left(\mathrm{X}_{2}\right)$ \\
\hline Net Profit Margin $(\mathrm{NPM})\left(\mathrm{X}_{3}\right)$ \\
\hline Eross Profit Margin $(\mathrm{GPM})\left(\mathrm{X}_{4}\right)$ \\
\hline Economic Value Added $(\mathrm{EVA})\left(\mathrm{X}_{5}\right)$ \\
\hline
\end{tabular}

\section{Gambar 1 \\ Model Penelitian}

\section{METODA PENELITIAN}

\section{Populasi dan Sampel}

Perusahaan yang menjadi populasi pada penelitian ini adalah semua perusahaan publik yang telah terdaftar dalam kelompok saham aktif LQ 45 berdasarkan klasifikasi BEI tahun 2008-2012. Sampel dipilih dengan menggunakan teknik purposive sampling dengan kriteria sebagai berikut:

1. Saham merupakan saham-saham yang masuk kriteria saham aktif, yaitu saham perusahaan tercatat yang masuk dalam penghitungan indeks LQ 45 aktif periods 2008-2012.

2. Perusahaan selalu masuk dalam daftar LQ 45 selama perioda penelitian yaitu 2008-2012.

3. Memiliki kelengkapan informasi sesuai dengan kriteria yang diterapkan yaitu variabel yang digunakan adalah pertumbuhan ROI, EPS, NPM, GPM dan EVA.

\section{Definisi Operasional Variabel}

\section{Return Saham}

Konsep return saham dalam penelitian ini adalah harga saham saat ini dikurangi harga saham perioda sebelumnya, kemudian dibandingkan dengan harga 
saham perioda sebelumnya. Return saham yang digunakan dalam penelitian ini selama 11 hari disekitar tanggal publikasi yaitu lima hari sebelum publikasi, saat publikasi, dan lima hari setelah publikasi. Return saham dapat dirumuskan sebagai berikut:

$$
\mathrm{Rt}=\frac{\mathrm{Pt}-\mathrm{P}(\mathrm{t}-1)}{\mathrm{P}(\mathrm{t}-1)}
$$

Keterangan:

$P_{t}=$ harga saham pada hari ke $\mathrm{t}$

$P_{t-1}=$ harga saham pada hari sebelumnya

\section{ROI}

ROI adalah rasio yang dirumuskan sebagai berikut:

$$
\text { ROI }=\frac{\text { Laba Setelah Pajak (EAT) }}{\text { Total Aset }}
$$

\section{EPS}

EPS dapat dirumuskan sebagai berikut:

$$
\mathrm{EPS}=\frac{\text { Laba Bersih }}{\text { Jumlah Saham Beredar }}
$$

Jika perusahaan tersebut terdapat saham preferen maka rumusnya sedikit berbeda, yaitu:

$$
\mathrm{EPS}=\frac{\text { Laba Bersih }- \text { Dividen Saham Preferen }}{\text { Jumlah Saham Biasa Beredar }}
$$

\section{NPM}

NPM adalah rasio antara laba setelah pajak (EAT) dengan penjualan. 


$$
\mathrm{NPM}=\frac{\text { Laba Setelah Pajak }}{\text { Penjualan }}
$$

\section{GPM}

GPM dapat dirumuskan sebagai berikut:

$$
\mathrm{GPM}=\frac{\text { Penjualan }- \text { Harga Pokok Penjualan }}{\text { Penjualan }}
$$

\section{EVA}

Menurut Higgins (1998) dalam Mila Christanty (2009), EVA adalah ukuran kinerja keuangan yang paling baik untuk menjelaskan economic profit suatu perusahaan, dibandingkan dengan ukuran yang lain. Keunggulan EVA sebagai pengukur kinerja terletak pada kemampuannya untuk menyatukan tiga fungsi penting manajemen, yaitu capital budgeting, performance appraisal dan incentive compensation. Langkah-langkah menghitung EVA:

1. Menghitung nilai laba operasi bersih setelah pajak (NOPAT)

$$
\text { NOPAT }=\text { EBIT } \mathrm{x}(1-\text { Tax rate })
$$

2. Menghitung nilai Invested Capital (IC)

IC = Jumlah Kewajiban dan Ekuitas - Kewajiban Lancar yang tidak mengandung bunga.

3. Menghitung biaya modal rata-rata tertimbang/Weight Average Cost of Capital $\mathrm{WACC}=\{\mathrm{D} \times \mathrm{rd}(1-\mathrm{T})+(\mathrm{E}$ Xre $)\}$

Keterangan :

- Menghitung tingkat modal dari hutang (D)

$$
\mathrm{D}=\frac{\text { Total Utang }}{\text { Total Utang \& Ekuitas }}
$$

- Menghitung biaya hutang jangka pendek (rd) 
Cost of Debt $=\frac{\text { Biaya Bunga }}{\text { Total Utang }}$

- Menghitung pajak penghasilan (tax)

Tingkat Pajak $(\mathrm{T})=\frac{\text { Beban Pajak }}{\text { Laba Sebelum Pajak }}$

- Menghitung cost of equity (re)

$$
\text { Cost of Equity }=\frac{1}{\text { PER }}
$$

$$
\text { PER }=\frac{\text { Harga Saham }}{\text { EPS }}
$$

- Menghitung tingkat bunga dari ekuitas (E)

$$
\text { Tingka Modal }(E)=\frac{\text { Total Ekuitas }}{\text { Total Utang \& Ekuitas }}
$$

4. Menghitung capital charges

Capital Charges $=$ WACC x Invested Capital

5. Menghitung nilai EVA

$\mathrm{EVA}=$ NOPAT - Capital Charges

\section{Teknik Analisis Data}

Peneliti menggunakan analisis regresi linier berganda. Sebelum melakukan uji regresi linier berganda, metoda ini mensyaratkan untuk melakukan uji asumsi klasik guna mendapatkan hasil terbaik (Ghozali, 2001). 


\section{Uji Asumsi Klasik}

\section{Uji Normalitas}

Uji normalitas bertujuan untuk menguji apakah dalam model regresi, variabel pengganggu atau residual memiliki distribusi normal atau tidak. Cara yang digunakan untuk mendeteksi residual berdistribusi normal adalah menggunakan uji statistik Kolmogorov-Smirnov (K-S). Ghozali (2011) menjelaskan apabila nilai signifikansi $<0,05$ maka data residual tidak berdistribusi normal dan sebaliknya.

\section{Uji Multikolinieritas}

Menurut Ghozali (2006), uji multikolinearitas bertujuan untuk menguji dalam model regresi ditemukan adanya korelasi antar variabel independen. Ada tidaknya multikolinearitas dalam model regresi, dapat dilihat dari tolerance value dan variance inflation factor (VIF). Nilai tolerance yang rendah sama dengan nilai VIF yang tinggi (karena VIF = 1/tolerance). Nilai cutoff yang umum dipakai untuk menunjukkan adanya multikolinearitas adalah nilai tolerance $\leq 0,10$ atau sama dengan nilai $\mathrm{VIF} \geq 10$.

\section{Uji Autokorelasi}

Uji autokorelasi bertujuan untuk menguji dalam model regresi linear ada korelasi antara kesalahan pengganggu dalam perioda $t$ dengan kesalahan pengganggu pada perioda t-1 (sebelumnya). Jika terjadi korelasi, maka terdapat problem autokorelasi. Teknik pengujian autokorelasi dapat dilakukan dengan Durbin Watson Test (DW test). Jika angka Durbin Watson di bawah -2 sampai +2 berarti tidak ada autokorelasi (Santoso, 2000).

\section{Uji Heteroskedastisitas}

Ada beberapa cara atau teknik yang dapat digunakan untuk mendeteksi adanya heteroskedastisitas, yaitu uji Park, uji Breusch Pagan Godfrey, dan uji White. Penelitian ini menggunakan uji Park. Kriteria uji yang digunakan untuk melihat adanya heteroskedastisitas adalah jika pengujian $\mathrm{F}$ signifikan $<0,05$ maka 
menunjukkan terjadinya heteroskedastisitas, sedangkan jika sig $\mathrm{F} \geq 0,05$ maka tidak terjadi heteroskedastisitas.

\section{Pengujian Hipotesis}

Model penelitian ini secara matematis dapat ditulis sebagai berikut:

$$
Y=\alpha+\beta_{1} X_{1}+\beta_{2} X_{2}+\beta_{3} X_{3}+\beta_{4} X_{4}+\beta_{5} X_{5}+e
$$

Keterangan:

$$
\begin{array}{ll}
\mathrm{Y} & =\text { Return Saham } \\
\alpha & =\text { Konstanta } \\
\beta_{1-\beta} \beta_{5} & =\text { Koefisien Regresi } \\
\mathrm{X}_{1} & =\text { ROI } \\
\mathrm{X}_{2} & =\mathrm{EPS} \\
\mathrm{X}_{3} & =\mathrm{NPM} \\
\mathrm{X}_{4} & =\mathrm{GPM} \\
\mathrm{X}_{5} & =\text { EVA } \\
\mathrm{e} & =\text { Error }
\end{array}
$$

\section{Uji Koefisien Determinasi $\left(\mathbf{R}^{\mathbf{2}}\right)$}

Uji koefisien determinasi merupakan suatu alat untuk mengukur besarnya kontribusi variabel bebas terhadap variabel terikat. Besarnya koefisien determinasi berkisar antara angka 0 sampai dengan 1, semakin mendekati 0 besarnya koefisien determinasi suatu persamaan regresi, maka semakin kecil kontribusi semua variabel independen terhadap variabel dependen.

\section{Uji F (Simultan)}

Uji F dilakukan untuk melihat pengaruh variabel independen secara bersamasama terhadap variabel dependen. Jika pengujian $\mathrm{F}$ signifikan ( $\operatorname{sig} \mathrm{F}<0,05)$ maka menunjukkan bahwa terdapat pengaruh variabel independen secara bersama-sama atau setidaknya ada satu variabel independen yang berpengaruh terhadap variabel dependen, sedangkan jika sig $\mathrm{F} \geq 0,05$ maka tidak ada pengaruh. 


\section{Uji t (Parsial)}

Uji t dilakukan untuk mengetahui pengaruh masing-masing rasio keuangan secara individu terhadap minimalisasi risiko. Jika dalam model regresi signifikan ( $\operatorname{sig} \mathrm{t}<0,05)$ maka menunjukkan terdapat pengaruh masing-masing rasio keuangan secara individual terhadap return saham, sedangkan jika sig $\mathrm{t} \geq 0,05$ maka tidak ada pengaruh.

\section{HASIL DAN PEMBAHASAN}

Objek penelitian yang digunakan adalah perusahan yang terklasifikasi dalam LQ 45 perioda 2008 sampai tahun 2012.

\section{Tabel 1}

\section{Daftar Nama Perusahaan yang Dijadikan Objek Penelitian}

\begin{tabular}{|r|l|c|}
\hline \multicolumn{1}{|c|}{ No. } & \multicolumn{1}{|c|}{ Nama Perusahaan } & Kode Saham \\
\hline 1. & Astra Agro Lestari Tbk & AALI \\
\hline 2. & Aneka Tambang (Persero) Tbk & ANTM \\
\hline 3. & Astra International Tbk & ASII \\
\hline 4. & Indofood Sukses Makmur Tbk & INDF \\
\hline 5. & Indo Tambangraya Megah Tbk & ITMG \\
\hline 6. & Lippo Karawaci Tbk & LPKR \\
\hline 7. & PP London Sumatera Tbk & LSIP \\
\hline 8. & Perusahaan Gas Negara (Persero) Tbk & PGAS \\
\hline 9. & Tambang Batubara Bukit Asam Tbk & PTBA \\
\hline 10. & Semen Gresik (Persero) Tbk & SMGR \\
\hline 11. & Timah Tbk & TINS \\
\hline 12. & United Tractors Tbk & UNTR \\
\hline
\end{tabular}

Sumber: ICMD 


\section{Uji Asumsi Klasik}

\section{Uji Normalitas}

Tabel 2

Ringkasan Uji Normalitas (Kolmogorov-Smirnov)

\begin{tabular}{|c|c|}
\hline Keterangan & Asymp. Sig (2 tailed) \\
\hline Return $\mathrm{H}+5$ & 0,450 \\
\hline Return $\mathrm{H}+4$ & 0,158 \\
\hline Return $\mathrm{H}+3$ & 0,437 \\
\hline Return $\mathrm{H}+2$ & 0,471 \\
\hline Return $\mathrm{H}+1$ & 0,305 \\
\hline Return $\mathrm{H}$ & 0,191 \\
\hline Return $\mathrm{H}-1$ & 0,936 \\
\hline Return $\mathrm{H}-2$ & 0,570 \\
\hline Return $\mathrm{H}-3$ & 0,883 \\
\hline Return $\mathrm{H}-4$ & 0,511 \\
\hline Return $\mathrm{H}-5$ & 0,131 \\
\hline
\end{tabular}

Sumber: Data sekunder, diolah (2013)

Berdasar tabel 2 menunjukkan bahwa data residual berdistribusi normal, hal ini dapat dilihat dari nilai signifikansi > 0,05, pada saat return $\mathrm{H}-5$ sampai dengan return $\mathrm{H}+5$.

\section{Uji Multikolinearitas}

Tabel 3

Ringkasan Uji Multikolinearitas

\begin{tabular}{|l|l|l|l|l|l|}
\hline \multirow{2}{*}{ Ket } & \multicolumn{5}{|c|}{ VIF } \\
\cline { 2 - 6 } & ROI & NPM & GPM & EPS & EVA \\
\hline Return $\mathrm{H}+5$ & 1,290 & 1,367 & 1,106 & 1,144 & 1,085 \\
\hline Return $\mathrm{H}+4$ & 1,289 & 1,361 & 1,106 & 1,133 & 1,074 \\
\hline Return $\mathrm{H}+3$ & 1,289 & 1,359 & 1,104 & 1,134 & 1,072 \\
\hline Return $\mathrm{H}+2$ & 1,296 & 1,380 & 1,100 & 1,144 & 1,094 \\
\hline Return $\mathrm{H}+1$ & 1,290 & 1,369 & 1,107 & 1,142 & 1,087 \\
\hline Return $\mathrm{H}$ & 1,292 & 1,367 & 1,108 & 1,144 & 1,085 \\
\hline Return $\mathrm{H}-1$ & 1,291 & 1,368 & 1,107 & 1,141 & 1,085 \\
\hline Return $\mathrm{H}-2$ & 1,291 & 1,370 & 1,107 & 1,142 & 1,087 \\
\hline Return $\mathrm{H}-3$ & 1,291 & 1,370 & 1,107 & 1,142 & 1,087 \\
\hline Return $\mathrm{H}-4$ & 1,290 & 1,370 & 1,107 & 1,142 & 1,087 \\
\hline Return $\mathrm{H}-5$ & 1,295 & 1,365 & 1,107 & 1,138 & 1,078 \\
\hline
\end{tabular}

Sumber: Data sekunder, diolah (2013) 
Hasil uji multikolinearitas saat return $\mathrm{H}-5$ sampai $\mathrm{H}+5$ mempunyai nilai VIF $\leq 10$ yang menunjukkan bahwa variabel bebas dari multikolinearitas.

\section{Uji Autokorelasi}

Tabel 4

Keputusan Autokorelasi

\begin{tabular}{|l|l|}
\hline \multicolumn{1}{|c|}{ DW } & \multicolumn{1}{c|}{ Simpulan } \\
\hline Kurang dari 1,10 & Ada autokorelasi \\
\hline Antara 1,10 sampai 1,54 & Tanpa simpulan \\
\hline Antara 1,55 sampai 2,46 & Tidak ada autokorelasi \\
\hline Antara 2,47 sampai 2,90 & Tanpa simpulan \\
\hline Lebih dari 2,91 & Ada autokorelasi \\
\hline
\end{tabular}

Tabel 5

Ringkasan Uji Autokorelasi

\begin{tabular}{|c|c|}
\hline Keterangan & Durbin- Watson (DW Test) \\
\hline Return $\mathrm{H}+5$ & 1,918 \\
\hline Return $\mathrm{H}+4$ & 1,561 \\
\hline Return $\mathrm{H}+3$ & 2,179 \\
\hline Return $\mathrm{H}+2$ & 2,136 \\
\hline Return $\mathrm{H}+1$ & 1,874 \\
\hline Return $\mathrm{H}$ & 1,744 \\
\hline Return $\mathrm{H}-1$ & 2,024 \\
\hline Return $\mathrm{H}-2$ & 2,274 \\
\hline Return $\mathrm{H}-3$ & 2,109 \\
\hline Return $\mathrm{H}-4$ & 1,737 \\
\hline Return $\mathrm{H}-5$ & 1,844 \\
\hline
\end{tabular}

Sumber: Data sekunder, diolah (2013)

Tabel 5 menunjukkan bahwa variabel bebas dari autokorelasi karena angka Durbin-Watson antara 1,55 sampai 2,46.

\section{Uji Heteroskedastisitas}

Tabel 6 menunjukkan bahwa semua variabel bebas dari heteroskedastisitas, hal ini karena nilai $\operatorname{sig} \mathrm{F} \geq 0,05$. 
Tabel 6

Ringkasan signifikansi F (anova abs_res sebagai dependen)

\begin{tabular}{|c|c|}
\hline Keterangan & Sig F \\
\hline Return $\mathrm{H}+5$ & 0,694 \\
\hline Return $\mathrm{H}+4$ & 0,893 \\
\hline Return $\mathrm{H}+3$ & 0,360 \\
\hline Return $\mathrm{H}+2$ & 0,142 \\
\hline Return $\mathrm{H}+1$ & 0,096 \\
\hline Return $\mathrm{H}$ & 0,390 \\
\hline Return $\mathrm{H}-1$ & 0,589 \\
\hline Return $\mathrm{H}-2$ & 0,459 \\
\hline Return $\mathrm{H}-3$ & 0,159 \\
\hline Return $\mathrm{H}-4$ & 0,552 \\
\hline Return $\mathrm{H}-5$ & 0,962 \\
\hline
\end{tabular}

Sumber: Data sekunder, diolah (2013)

\section{Pengujian Hipotesis}

\section{Koefisien Determinasi}

Berdasar tabel 7 nilai R square tertinggi yaitu pada saat return H-3 (0,245), berarti bahwa pada saat return H-4 variabel-variabel independen memberikan informasi yang paling banyak untuk memprediksi variabel dependen, sedangkan pada saat return H-5 $(0,004)$ memberikan informasi yang paling sedikit untuk memprediksi variabel dependen.

Tabel 7

\section{Ringkasan Koefisien Determinasi}

\begin{tabular}{|c|c|c|}
\hline Keterangan & R & R- Square \\
\hline Return $\mathrm{H}+5$ & 0,227 & 0,077 \\
\hline Return $\mathrm{H}+4$ & 0,156 & 0,024 \\
\hline Return $\mathrm{H}+3$ & 0,168 & 0,028 \\
\hline Return $\mathrm{H}+2$ & 0,352 & 0,124 \\
\hline Return $\mathrm{H}+1$ & 0,310 & 0,096 \\
\hline Return $\mathrm{H}$ & 0,382 & 0,146 \\
\hline Return $\mathrm{H}-1$ & 0,444 & 0,198 \\
\hline Return $\mathrm{H}-2$ & 0,329 & 0,108 \\
\hline Return $\mathrm{H}-3$ & 0,495 & 0,245 \\
\hline Return $\mathrm{H}-4$ & 0,430 & 0,185 \\
\hline Return $\mathrm{H}-5$ & 0,064 & 0,004 \\
\hline
\end{tabular}

Sumber: Data sekunder, diolah (2013) 


\section{Uji F}

Berdasar tabel 8, variabel independen ROI, NPM, GPM, EPS, dan EVA pada return $\mathrm{H}-1, \mathrm{H}-3$, dan $\mathrm{H}-4$ berpengaruh secara bersama-sama pada variabel dependen return saham, karena mempunyai nilai signifikansi $>0,05$.

Tabel 8

Ringkasan Uji F (anova)

\begin{tabular}{|c|c|}
\hline Keterangan & Sig F \\
\hline Return $\mathrm{H}+5$ & 0,487 \\
\hline Return $\mathrm{H}+4$ & 0,929 \\
\hline Return $\mathrm{H}+3$ & 0,902 \\
\hline Return $\mathrm{H}+2$ & 0,198 \\
\hline Return $\mathrm{H}+1$ & 0,348 \\
\hline Return $\mathrm{H}$ & 0,120 \\
\hline Return $\mathrm{H}-1$ & $0,032^{*}$ \\
\hline Return $\mathrm{H}-2$ & 0,271 \\
\hline Return $\mathrm{H}-3$ & $0,008^{*}$ \\
\hline Return $\mathrm{H}-4$ & $0,045^{*}$ \\
\hline Return $\mathrm{H}-5$ & 0,999 \\
\hline
\end{tabular}

Sumber: Data sekunder, diolah (2013)

Uji t

Tabel 9

Ringkasan Uji t

\begin{tabular}{|c|c|c|c|c|c|}
\hline \multirow{2}{*}{ Ket } & \multicolumn{5}{|c|}{ Uji t } \\
\cline { 2 - 6 } & ROI & NPM & GPM & EPS & EVA \\
\hline Return $\mathrm{H}+5$ & 0,207 & 0,557 & 0,307 & 0,966 & 0,209 \\
\hline Return $\mathrm{H}+4$ & 0,817 & 0,670 & 0,439 & 0,866 & 0,622 \\
\hline Return $\mathrm{H}+3$ & 0,550 & 0,315 & 0,478 & 0,948 & 0,706 \\
\hline Return $\mathrm{H}+2$ & 0,363 & 0,137 & 0,043 & 0,458 & 0,196 \\
\hline Return $\mathrm{H}+1$ & 0,029 & 0,408 & 0,512 & 0,971 & 0,609 \\
\hline Return $\mathrm{H}$ & 0,802 & 0,359 & 0,337 & 0,021 & 0,437 \\
\hline Return $\mathrm{H}-1$ & 0,036 & 0,372 & 0,597 & 0,287 & 0,116 \\
\hline Return $\mathrm{H}-2$ & 0,370 & 0,411 & 0,734 & 0,210 & $0,039^{*}$ \\
\hline Return $\mathrm{H}-3$ & 0,011 & 0,385 & 0,383 & 0,277 & $0,016^{*}$ \\
\hline Return $\mathrm{H}-4$ & 0,339 & 0,003 & 0,344 & 0,796 & 0,712 \\
\hline Return $\mathrm{H}-5$ & 0,989 & 0,775 & 0,852 & 0,795 & 0,934 \\
\hline
\end{tabular}

Sumber: Data sekunder, diolah (2013) 


\section{Pengujian Signifikan Koefisien dengan Uji t \\ Pengaruh ROI terhadap Return Saham}

Hasil uji t pada tabel 9 menunjukkan bahwa ROI berpengaruh terhadap return saham yaitu pada return H+1 (0,029), H-1 (0,036), dan H-3 (0,011). ROI semakin meningkat menunjukkan kinerja perusahaan yang semakin baik dan para pemegang saham akan memperoleh keuntungan dari dividen yang diterima. Penerimaan dividen yang semakin meningkat, merupakan daya tarik bagi para investor/calon investor untuk menanamkan modalnya ke dalam perusahaan tersebut. Jika permintaan atas saham perusahaan semakin banyak maka harga saham perusahaan tersebut di pasar modal cenderung meningkat.

\section{Pengaruh NPM terhadap Return Saham}

Hasil uji t pada tabel 9 menunjukkan bahwa NPM berpengaruh terhadap return saham yaitu pada return $\mathrm{H}-4$, karena $0,003<0,05$. Rasio ini bermanfaat untuk mengukur tingkat efisiensi total pengeluaran biaya-biaya operasional dalam perusahaan. Semakin efisien suatu perusahaan dalam mengeluarkan biayabiayanya, maka semakin besar tingkat keuntungan (return) yang akan diperoleh perusahaan tersebut. Meningkatnya keuntungan yang didapat perusahaan menyebabkan investor tertarik menanamkan modalnya di perusahaan tersebut, kemudian menyebabkan harga saham naik dan return saham yang diperoleh investor juga akan meningkat.

\section{Pengaruh GPM terhadap Return Saham}

Hasil uji t pada tabel 9 menunjukkan bahwa GPM berpengaruh terhadap return saham yaitu pada return $\mathrm{H}+2$, karena $0,043<0,05$. GPM yang rendah mencerminkan perusahaan tersebut rawan terhadap perubahan harga baik harga jual dan harga pokok. GPM yang meningkat menunjukkan bahwa semakin besar laba kotor yang diterima perusahaan terhadap penjualan bersihnya. Ini berarti bahwa kinerja perusahaan dinilai baik dan dapat meningkatkan daya tarik investor untuk 
menanamkan dananya pada perusahaan tersebut. Sehingga harga saham naik dan return yaang didapat investor akan meningkat.

\section{Pengaruh EPS terhadap Return Saham}

Hasil uji t pada tabel 9 menunjukkan bahwa EPS berpengaruh terhadap return saham yaitu pada return $\mathrm{H}$, karena $0,021<0,05$. Semakin tinggi laba perusahaan yang diberikan kepada para pemegang saham akan menambah daya tarik investor dan mendorong untuk memiliki saham tersebut, sehingga menyebabkan meningkatnya harga saham.

\section{Pengaruh EVA terhadap return saham}

Hasil uji t pada tabel 9 menunjukkan bahwa EVA berpengaruh terhadap return saham yaitu pada return H-2 (0,021), dan H-3 (0,016). Hasil pengujian ini menunjukkan bahwa kemampuan perusahaan untuk meningkatkan nilai untuk kemakmuran para pemegang sahamnya dapat menimbulkan meningkatnya harga saham. Hal ini disebabkan peningkatan EVA mengindikasikan kemakmuran yang ada pada perusahaan, sehingga secara tidak langsung akan berdampak pada return saham perusahaan yang terdaftar dalam LQ 45 di BEI.

\section{SIMPULAN, KETERBATASAN, SAN SARAN}

Berdasarkan analisis yang dilakukan dalam penelitian ini menyimpulkan bahwa return on investment (ROI), net profit margin (NPM), gross profit margin (GPM), earning per share (EPS), dan economic value added (EVA) memiliki pengaruh terhadap return saham.

Keterbatasan dalam penelitian ini adalah hasil koefisien determinasi yang diperoleh dari hasil analisis hanya sebesar 24,5\% saja, yang berarti kemampuan variabel independen dalam menjelaskan variasi variabel dependen amat terbatas. Hasil yang diperoleh pada penelitian ini masih jauh dari cukup, sehingga masih perlu adanya penambahan variabel pada penelitian mendatang. 
Berdasar simpulan dan keterbatasan yang ada, beberapa saran yang dapat peneliti ajukan penelitian ke depan yaitu perlu menambah atau memasukkan variabel lain berupa variabel fundamental yang dapat berpengaruh terhadap return saham sehingga nilai koefisien determinasinya dapat lebih bervariasi secara signifikan dan dapat ditingkatkan, sehingga permodelan menjadi lebih komplek.

\section{DAFTAR PUSTAKA}

Amalia, Tiara. 2011. Pengaruh Kinerja Keuangan terhadap Harga Saham (Studi Kasus pada Perusahaan Properti dan Real Estate yang Terdaftar di BEI). Jurnal. Jakarta: Universitas Gunadarma.

Anastasia, Nuri. 2011. Pengaruh Kinerja Keuangan terhadap Return Saham Perusahaan yang Terdaftar di LQ 45. Skripsi. Yogyakarta: Universitas Ahmad Dahlan.

Ang, Robert. 1997. Buku Pintar Pasar Modal Indonesia (The Intelegent Guideto Indonesian Capital Market). Jakarta: Mediasoft Indonesia.

Aulianto, Sita. 2008. Pengaruh EPS, Operating Cash Flow (OCF), dan EVA terhadap Return Saham Perusahaan yang Terdaftar di BEJ. Skripsi. Yogyakarta: Universitas Ahmad Dahlan.

Christanty, Mila. 2009. Analisis Faktor Fundamental dan Economic Value Added (EVA) terhadap Return Saham pada Perusahaan LQ 45. Tesis.

Dwi, Sonnya Titin. 2009. Pengaruh Rasio Profitabilitas terhadap Return Saham pada Perusahaan Manufaktur (Studi Empiris pada Perusahaan Manufaktur di BEI tahun 2004-2007). Skripsi . Solo: Universitas Muhammadiyah Surakarta.

Fakhruddin, Hendy. 2006. Pasar Modal di Indonesia: Pendekatan Tanya Jawab. Jakarta: Salemba Empat

Ghozali, Imam. 2001. Aplikasi Analisis Multivariate dengan Program SPSS. Edisi Kedua. Semarang: BP- UNDIP. 
Ghozali. Imam. 2011. Aplikasi Analisis Multivariate dengan Program IBM SPSS 19. Semarang: Universitas Diponegoro.

Hartono, Jogiyanto. 2003. Teori Portofolio dan Analisis Investasi. Yogyakarta: BPFE-Yogyakarta.

Hidayatulloh, Amir. 2012. Pengaruh Pertumbuhan EPS, DPS, ROI dan ROE terhadap Return Saham Perusahaan yang Terdaftar di LQ 45. Skripsi. Yogyakarta: Universitas Ahmad Dahlan.

Husnan, Suad. 1998. Manajemen Keuangan dan Penerapan (Keputusan Jangka Pendek). Yogyakarta: BPFE.

Kurniawati, Indah. 2006. Modul Pengolahan Data Elektronik. Yogyakarta: Universitas Ahmad Dahlan.

Lestari, Murti. 2005. Pengaruh Variabel Makro terhadap Return Saham di BEJ. Seminar Nasional Akuntansi VIII. Padang: Universitas Kristen Duta Kencana.

Maftukhah, Intan Tadzkhirotul. 2011. Pengaruh Faktor-Faktor Fundamental yang Mempengaruhi Harga Saham pada Perusahaan Food and Beverages yang Terdaftar di BEI tahun 2008-2010. Jurnal Dinamika Manajemen Vol. 1 No. 1, hlm.78-92.

Martono. 2008. Manajemen Keuangan. Yogyakarta: EKONISIA.

Mayasari, Diana. 2006. Pengaruh ROI dan EVA terhadap Return Saham. Skripsi. Malang: Universitas Muhammadiyah Malang.

Mirza, Tengku dan Imbuh S. 1999. Konsep Economic Value Added (EVA): Pendekatan untuk Menentukan Nilai Riil Perusahaan dan Kinerja Riil Manajemen. No. 1 Th. XXVIII, (Januari), hal. 37-40.

Mulyanti, Santri. 2009. Analisis Pengaruh ROI dan EVA terhadap Return Saham pada Perusahaan Manufaktur yang Terdaftar di BEJ. Skripsi. Yogyakarta: Universitas Ahmad Dahlan. 
Nur Indriantoro dan Bambang Supomo. 1999. Metodologi Penelitian Bisnis untuk Akuntansi dan Manajemen Edisi pertama. Yogyakarta: BPFE.

Riyani, Ica. 2011. Analisis Pengaruh Rasio Profitabilitas terhadap Return Saham pada Perusahaan LQ 45 di BEI. Skripsi. Yogyakarta: Universitas Ahmad Dahlan.

Santosa, P.B, dan Ashari. 2005. Analisis Statistik dengan Microsoft Excel \& SPSS. Yogyakarta: ANDI Yogyakarta.

Sartono, Agus. 2000. Ringkasan Teori Manajemen dan Keuangan (Soal dan Penyelesaiannya). Yogyakarta: BPFE-Yogyakarta.

Savitri, Dyah Ayu. 2012. Analisis Pengaruh ROA, NPM, EPS dan PER terhadap Return Saham pada Perusahaan Manufaktur Sektor Food dan Beverages. Skripsi. Semarang: Universitas Negeri Diponegoro.

Tandelilin, Eduardus. 2001. Analisis Investasi dan Manajemen Portofolio. Yogyakarta: BPFE-Yogyakarta.

2007. Analisis Investasi dan Manajemen Portofolio. Yogyakarta: BPFE-Yogyakarta.

Trisnawati, Ita. 2009. Pengaruh Economic Value Added (EVA). Arus Kas Operasi, Residual Income, Earnings, Operating Leverage dan Market Value Added (MVA) terhadap Return Saham. Jurnal Bisnis dan Akuntansi Vol. 11 No. 1, hlm. 65-78.

Widiayanti, Novi Wulandari dan Fita Dianita. 2009. Pengaruh Rasio Leverage, Profitabilitas, dan Likuiditas terhadap Return Saham Aneka Industri yang Terdaftar di BEI tahun 2003-2008. Relasi Jurnal Ekonomi: STIE Mandala Jember.

Yusananta, Ryan Anggarapasha. 2007. Pengaruh Perubahan Rasio Profitabilitas dan Rasio Utang terhadap Perubahan Harga Saham Perusahaan Jasa Keuangan yang Terdaftar di BEJ. Tesis. Yogyakarta: Universitas Gadjah Mada. 